\title{
RUMAH INTI TUMBUH SEBAGAI UPAYA PENINGKATAN KELAYAKAN PERUMAHAN DI INDONESIA
}

\section{CORE HOUSE DEVELOPMENT AS AN EFFORTS TO INCREASE FEASIBILITY HOUSE IN INDONESIA}

\author{
Nike Tilamsari Hutoyo ${ }^{1}$, Ardhya Nareswari \\ 1,2 Magister Teknik Arsitektur, Universitah Gadjah Mada, Jl. Grafika No.2, \\ Senolowo, Sinduadi, Kec. Mlati, Kabupaten Sleman, Daerah Istimewa \\ Yogyakarta 55284 Yogyakarta \\ niketilam@gmail.com, nares@ugm.ac.id
}

\begin{abstract}
Abstrak: Tulisan ini fokus untuk mengkaji peranan kosep rumah inti tumbuh dalam meningkatkan kelayakan huni rumah dan perumahan di Indonesia. Rumah merupakan tempat yang sangat bernilai vital bagi perkembangan manusia, rumah merupakan tempat berlindung dan merupakan kebutuhan dasar dari manusia. Oleh karenanya rumah harus memiliki kelayakan untuk menopang segala aktivitas kehidupan sehari-hari secara normal. Namun kelayakan rumah dan perumahan masih menjadi suatu permasalahan di Indonesia, hal ini terjadi akibat pembangunan rumah dan perumahan yang tidak terlalu mempertimbangkan fungsionalitas melainkan lebih berorientasi pada profit. Penelitian ini menggunakan metode penelitian studi literatur. Konsep pengembangan rumah inti tumbuh dapat menjadi alternatif untuk meningkatkan kelayakan rumah dan perumahan di Indonesia dengan beberapa potensi, seperti desain yang sederhana, kemudahan konstruksi, dan keterjangkauan serta kelemahan, seperti dapat menciptakan kawasan kumuh jika tidak direncanakan dengan sebaik mungkin. Dengan keunggulan aspek ekonomi, produksi rumah inti tumbuh lebih fleksibel dan lebih ekonomis dibandingkan dengan proyek perumahan yang lebih canggih seperti flat atau apartemen.
\end{abstract}

Kata kunci : rumah inti tumbuh, kelayakan, fungsionalitas

Abstract: This paper focuses on examining the role of the growing core house concept in increasing the livability of houses and housing in Indonesia. The house is a very valuable place vital for human development, the house is a shelter and a basic human need. Therefore the house must have the feasibility to support all activities of normal daily life. However, the feasibility of houses and housing is still a problem in Indonesia, this is due to the construction of houses and housing that does not really consider functionality but is more profit-oriented. This study uses a literature study research method. The concept of developing core houses to grow can be an alternative to increase the feasibility of houses and housing in Indonesia with several potentials, such as simple design, ease of construction, and affordability and weaknesses, such as being able to create slum areas if not planned properly. With the advantages of the economic aspect, the production of core houses grows more flexible and more economical compared to more sophisticated housing projects such as flats or apartments.

Keywords: core house grows, feasibility, functionality

\section{PENDAHULUAN}

Rumah adalah tempat yang paling penting bagi kehidupan manusia. Rumah merupakan kebutuhan dasar selain sandang dan pangan. Rumah digunakan untuk memenuhi kebutuhan dasar manusia sebagai tempat untuk berlindung dari panas dan hujan serta berbagai ancaman dari alam (Soebroto, 2006). Rumah pada hakikatnya harus mampu memberikan keamanan, ketenangan hidup, kemesraan dan kehangatan hidup serta kebebasan (Poespowardojo, 2006). Berdasarkan Undang-undang No. 4 tahun 1992 tentang Perumahan dan Permukiman, rumah diartikan sebagai bangunan 
yang berfungsi sebagai tempat tinggal/hunian dan sarana pembinaan keluarga..Lebih luas lagi rumah tidak hanya diartikan sebagai sebuah bangunan, melainkan juga memiliki nilai-nilai ekonomi dan sosial. Sehingga dalam pembangunan rumah harus benar-benar memperhatikan kelayakannya.

Perkembangan rumah di Indonesia dapat dilihat dari perkembangan perumahan dan permukiman yang semakin meningkat. Menurut Undang-undang No. 4 tahun 1992 tentang Perumahan dan Permukiman, perumahan diartikan sebagai kelompok rumah yang berfungsi sebagai lingkungan tempat tinggal/hunian yang dilengkapi dengan sarana dan prasarana lingkungan. Sedangkan permukiman adalah bagian dari lingkungan hidup di luar kawasan lindung (kota dan desa) yang berfungsi sebagai lingkungan tempat tinggal/hunian dan tempat kegiatan yang mendukung perikehidupan dan penghidupan.

Rumah memiliki arti yang lebih luas dari sekedar bangunan fisik semata. yaitu sebagai tempat tinggal atau hunian dan sarana pembinaan keluarga. Budiharjo dan Hardjohubojo (1993:111) mengatakan konsep perumahan sebagai wadah pembinaan keluarga perlu disebarluaskan agar penduduk betah tinggal dilingkungan masingmasing. Nanun, seringkali rumah hanya dipandang sebagai bangunan fisik semata, akibatnya penyedian perumahan hanya untuk mencapai target kuantitas semata tanpa memperhatikan kualitas dan mutu perumahan tersebut. Salah satu solusi yang dapat diterapkan guna meningkatkan kelayakan sebuah rumah tinggal adalah dengan menerapkan konsep rumah inti tumbuh. Untuk itu dalam tulisan ini, penulis memaparkan konsep rumah inti tumbuh dan potensi rumah inti tumbuh untuk mengatasi permasalahan perumahan yang terjadi di Indonesia.

\section{METODE PENELITIAN}

Penelitian ini menggunakan metode penelitian studi literatur. Berdasarkan studi literatur pada tinjauan pustaka dibentuklah pertanyaan penelitian yaitu 1). Bagaimana permasalahan kelayakan perumahan di Indonesia dan 2). Bagaimana potensi dan kekurangan pengembangan rumah inti tumbuh sebagai upaya mengatasi permasalahan perumahan. Jenis data yang digunakan adalah data sekunder. Metode pengumpulan data adalah studi pustaka. Metode yang akan digunakan untuk pengkajian ini studi literatur. Data yang diperoleh dikompulasi, dianalisis, dan disimpulkan sehingga mendapatkan kesimpulan mengenai permasalahan perumahan di Indonesia serta potensi dan kekurangan pengembangan rumah inti tumbuh sebagai upaya mengatasi permasalahan perumahan.

\section{HASIL \& PEMBAHASAN}

\subsection{Rumah Inti Tumbuh}

E.E. Pandelaki (2010), rumah inti tumbuh merupakan pembangunan rumah secara bertahap. Rumah inti tumbuh juga merupakan suatu cara yang tempat dan ringan bagi mereka yang berpenghasilan kecil dan berminat membangun rumahnya sendiri secara berangsur dan bertahap. Selanjutnya Dewi (2017), berkaitan dengan rumah inti tumbuh menjelaskan bahwa rumah tinggal senantiasa mengalami pertumbuhan dalam 
beberapa tahapan sebelum mencapai rumah yang diharapkan. Desain awal rumah yang minimalis yang dapat mewadahi aktivitas dasar manusia dalam rumah yang kemudian dikembangkan sesuai dengan perkembangan kebutuhan. Selain itu menurut menyatakan bahwa rumah inti tumbuh dapat diartikan sebagai rumah yang dikembangkan dari ukuran mungil menjadi rumah yang lebih luas dan besar. Membangun rumah inti tumbuh dapat dilakukan secara bertahap sesuai kemampuan keuangan demi menanggapi perkembangan kebutuhan ruangan dimasa sekarang dan ditambahkan ruang-ruang baru. (Napir, 2002; Agusniansyah, 2013). Maka secara garis besar, rumah inti tumbuh dapat diartikan sebagai pembangunan rumah yang dilakukan secara bertahap dengan cara menambahkan ruang-ruang tertentu sesuai dengan kebutuhan.

Perencanaan rumah inti tumbuh berdasarkan tahapan pembangunannya dapat dilakukan dengan mendesain denah ruang yang diperlukan secara keseluruhan. Denah ini merupakan acuan dalam tahapan pembangunan atau pengembangan rumah. Desain tersebut sudah harus mempertimbangkan mana yang akan dibangun ditahap awal, dan bagian mana yang dibangun dalam pengembangan selanjutnya. Artinya, dimasa depan, bisa dibangun tambahan ruang-ruang lain seperti ruang tidur, ruang keluarga, dan sebagainya tanpa harus melakukan banyak pembongkaran terhadap ruang-ruang yang sudah ada. Perlu diperhatikan juga, apakah rumah akan dikembangkan secara horizontal, atau vertikal. Bangunan rumah dapat dibangun satu lantai dulu, baru kemudian dikembangkan lagi dengan diperluas atau ditingkat. Rumah awal umumnya berupa rumah kecil dengan ruang-ruang pokok, yang kemudian dikembangkan dengan ruang-ruang tambahan.

\subsection{Faktor Yang Mempengaruhi Pengembangan Rumah Inti Tumbuh}

Rumah inti tumbuh mengalami proses transformasi atau perubahan fisik yang dapat berjalan dengan perencanaan maupun tanpa perencanaan, adapun proses perubahan menurut Alexandre (1987) di antaranya adalah:

a. Terjadi transfomasi sedikit demi sedikit (evolusi);

b. Tidak terduga kapan dimulai dan berakhirnya proses tersebut tergantung dari latar belakang proses terjadinya;

c. Proses terjadinya transformasi secara komprehensif dan berkesinambungan;

d. Transformasi yang terjadi mempunyai keterkaitan erat dengan emosional (sistem nilai) yang ada dalam populasi masyarakatnya.

Perubahan pada rumah inti tumbuh dapat dipengaruhi oleh dua faktor. Yang pertama adalah faktor internal, seperti penambahan jumlah keluarga, perkembangan kebutuhan, dan perubahan gaya hidup. Kedua adalah faktor eksternal yaitu faktor yang mempengaruhi sesorang yang berasal dari luar, seperti latar belakang budaya atau pendidikan. (Habraken, 1976). Selanjutnya, faktor perubahan rumah inti tunbuh berkaitan dengan, sosial budaya, lingkungan alam, dan teknologi. (Rapoport 1968 dalam Swanderi, dkk, 2010). Namun, pada tahun 1970, Rapoport menambahkan faktor dari transformasi atau perubahan rumah inti tumbuh meliputi, aktivitas, gaya hidup, serta rujukan nilai baru. Kemudian Swanderi, dkk (2010) mengungkapkan bebrapa faktor yang mendorong penghuni mengembangkan rumah inti tumbuh adalah sebagai berikut:

a. Kebutuhan identitas diri Pada dasarnya orang ingin dikenal dan ingin memperkenalkan diri terhadap lingkungan komunitasnya. Kebutuhan ini dapat 
kita lihat dalam hal pemilihan sandang, perabotan, kendaraan, dan barang-barang lainnya. Begitu juga pada saat penghuni merubah atau mengembangkan rumah yang seringkali pula dipergunakan sebagai alat untuk mengekspresikan diri.

b. Perubahan gaya hidup Perubahan gaya hidup disebabkan oleh perubahan struktur dalam masyarakat, pengaruh kontak dengan budaya lain ataupun munculnya pandangan baru tentang manusia dan lingkungan sehingga mempengaruhi gaya hidup seseorang.

c. Penggunaan teknologi baru Penemuan-penemuan baru dalam bidang teknologi menyebabkan timbulnya perasaan ingin mengikuti mode. Komponen bangunan yang masih dapat terpakai secara teknis kemudian diganti supaya jangan dianggap ketinggalan jaman, hal ini didukung pula dengan adanya produksi massal yang harganya relatif lebih murah. Atau karena umur material yang dipakai dalam suatu rumah sudah rusak sehingga membutuhkan penggantian.

d. Pertambahan anggota keluarga Bertambahnya penghuni dalam suatu keluarga akan mempengaruhi penambahan jumlah ruangan dan perabotan yang dibutuhkan oleh penghuni dalam beraktifitas sehari-hari. Walaupun demikian dorongan untuk memiliki hunian yang sesuai dengan kebutuhan dibatasi oleh faktor keterbatasan kondisi hunian tradisional.

Artinya, pengembangan rumah inti tumbuh memang sangat diperlukan, mengingat perkembangan kehidupan ekonomi, sosial, budaya mapun lingkungan yang berubah menuntut penyesuaian pada perkembangan tempat tinggal.

\subsection{Rumah Layak Huni}

Rumah memiliki peran yang sangat fital dalam kehidupan keluarga, untuk itu rumah tersebut harus memiliki kelayakan untuk menopang segala aktivitas kehidupan seharihari secara normal. Setiap masyarakat memiliki acuan ataupun pandangan yang berbeda-beda terkait tingkat kelayakan suatu hunian atau rumah, hal tersebut didasarkan pada tingkat kemampuan ekonomi dan tingkat kebutuhan. UN Universal Declaration of Human Rights dalam UNESCAP (2008) memberikan kriteria tentang kelayakan suatu hunian, diantaranya:

1. Pelayanan dasar dan infrastruktur: Sebuah tempat tinggal harus memiliki fasilitas yang memberikan kesehatan, keamanan, kenyamanan dan dukungan seperti air minum, bahan bakar untuk memasak, memanaskan, penerangan, fasilitas sanitasi, tempat pembuangan sampah, tempat penyimpanan dan pelayanan untuk kondisi darurat.

2. Keterjangkauan: Biaya yang dibutuhkan untuk tempat tinggal yang layak harus terjangkau agar tidak mengurangi kemampuan sebuah rumah tangga untuk memenuhi kebutuhannya.

3. Dapat ditinggali: Sebuah tempat tinggal harus mampu melindungi penghuninya dari udara dingin, panas, hujan atau ancaman terhadap kesehatan lainnya, serta ruang yang berkecukupan bagi penghuninya.

4. Aksesibilitas: Setiap orang berhak untuk memiliki perumahan yang layak dan kelompok marjinal juga harus memiliki akses terhadap tempat tinggal, yang memprioritaskan hak mereka dalam pengalokasian lahan ataupun perencanaan guna lahan.

5. Lokasi: Sebuah rumah tinggal harus terdapat di lokasi yang memiliki akses terhadap berbagai pilihan tempat kerja, pelayanan kesehatan, pendidikan, tempat penitipan anak dan fasilitas sosial lainnya. Hal ini berlaku di kota dan desa. 
Sebuah rumah tinggal juga harus tidak dibangun dekat daerah yang terpolusi ataupun sumber polusi.

6. Mencerminkan budaya: Dalam membangun area perumahan, harus dipastikan bahwa nilai-nilai budaya yang dimiliki penghuninya tercermin di dalamnya, namun tetap menggunakan fasilitas-fasilitas modern.

Sehingga dapat ditarik garis besar dari rumah layak huni adalah rumah yang sesuai dengan kebutuhan, nyaman untuk ditinggali, dan sesuai dengan tingkatan ekonomi.

\subsection{Permasalahan Perumahan Indonesia}

Membangun rumah sama dengan membangun kehidupan, terdapat banyak aspek yang harus diperhatikan, sehingga tidak dapat dibangun dengan seadanya. Aspek utama yang harus diperhatikan adalah permasalahan perekonomian. Dengan keterbatasan ekonomi, semakin banyak orang-orang yang menghuni rumah yang tidak layak. Dengan kata lain melakukan usaha pengentasan kemiskinan sama artinya dengan usaha meningkatkan kepemilikan rumah layak huni. Permasalahan lain yang kita jumpai saat ini adalah sulitnya mendapatkan rumah yang sehat dengan lingkungan yang bersih, lokasi yang strategis serta harga yang terjangkau (Hariyono, 2007).

Atas dasar pertimbangan bisnis, pengembang lebih suka membangun rumah yang layak untuk golongan menengah keatas. Membangun rumah sederhana sehat dianggap tidak menguntungkan karena adanya aturan dari pemerintah yang membatasi harga rumah tersebut. Sesuai dengan realita tersebut, hingga saat ini harga untuk sebuah rumah yang layak huni terus mengalami peningkatan. Hal tersebut tidak mampu menjawab permasalahan penyedian perumahan bagi masyarakat miskin dan berpenghasilan rendah. Masalah lainnya adalah terus meningkatnya pertumbuhan penduduk indonesia dengan sangat cepat, namun tidak diimbangi dengan pertumbuhan rumah layak huni yang terjangkau bagi masayarakat dengan perekonomian menengah ke bawah. Oleh sebab itu sesuai dengan apa yang dicitacitakan oleh PBB terkait perumahan terjangkau untuk masyarakat, pemerintah Indonesia menerapkan pembangunan perumahan berbasis rumah induk tumbuh (core housing).

\subsection{Perubahan pada Rumah Inti Tumbuh}

Permasalahan-permasalahan pada ketidaklayakan perumahan di Indonesia dapat di atasi dengan melakukan pelbagai jenis perubahan dalam kunsep rumah inti tumbuh, namun perubahan tersebut juga harus disesuaikan dengan kebutuhan masyarakat akan fungsi rumah sangat beraneka ragam. Oleh karenanya dalam pembangunan rumah inti tumbuh mengalami pertumbuhan rumah yang bermacam-macam sesuai dengan karakteristik dan kebutuhan penguninya. Budiharjo dalam Susetyo (2002) mengatakan bahwa ada 5 (lima) jenis dan tingkat perbaikan yang dilakukan penghuni terhadap rumah mereka yaitu :

a. Perombakan: perubahan struktur fisik rumah secara total (bentuk, bahan, jumlah ruang dan ukuran); Merupakan perbaikan Sangat berat.

b. Penyempurnaan: Peningkatan mutu bahan lantai, dinding dan atap secara menyeluruh tanpa mengubah jenis, jumlah dan bentuk rumah; Merupakan perbaikan berat

c. Ekpansi (perluasan): perluasan kearah luar, misalnya penambahan dapur, kamar, kamar mandi dan sebagainya; Merupakan perbaikan sedang. 
d. Penyempurnaan sebagian: Peningkatan mutu bahan sebagian rumah, misalnya peningkatan mutu bahan dinding atau lantai ruang tamu; Merupakan perbaikan ringan.

e. Pemeliharaan: Usaha mengatasi berbagai kerusakan, tanpa perubahan dan peningkatan mutu bahan misalnya menambal atap bocor, mengganti pintu yang lapuk, pengecatan dan sebagainya : dianggap tidak melakukan perbaikan.

Selain itu dalam pengembangannya dapat dilakukan secara horizontal maupun vertikal. Rumah inti tumbuh horizontal adalah rumah yang berkembang kearah samping, depan, maupun belakang, sehingga luasan rumah bertambah. Rumah yang tumbuh secara horizontal hanya dapat dikembangkan apabila terdapat lahan kosong untuk dibangun bangunan tambahan. Sedangkan rumah inti tumbuh vertikal merupakan rumah yang berkembang kearah atas, dengan kata lain perkembangan rumah menjadi rumah yang lebih dari satu lantai, sehingga ketinggian bangunan bertambah. Perencanaan rumah inti tumbuh vertikal dapat dilakukan jika lahan untuk pembangunan sangat terbatas. Kemudian dalam pembangunannya rumah tumbuh vertikal harus memiliki pondasi rumah yang kokoh. (Axellano, 2011). Dari setiap tipe perkembangan tumbuh tersebut terdapat keunggulam dan kelemahan masing-masing, serta dalam perkembangannya harus disesuaikan dengan rancangan awal dan lahan yang tersedia. Berikut beberapa contoh rancangan dari rumah inti tumbuh :

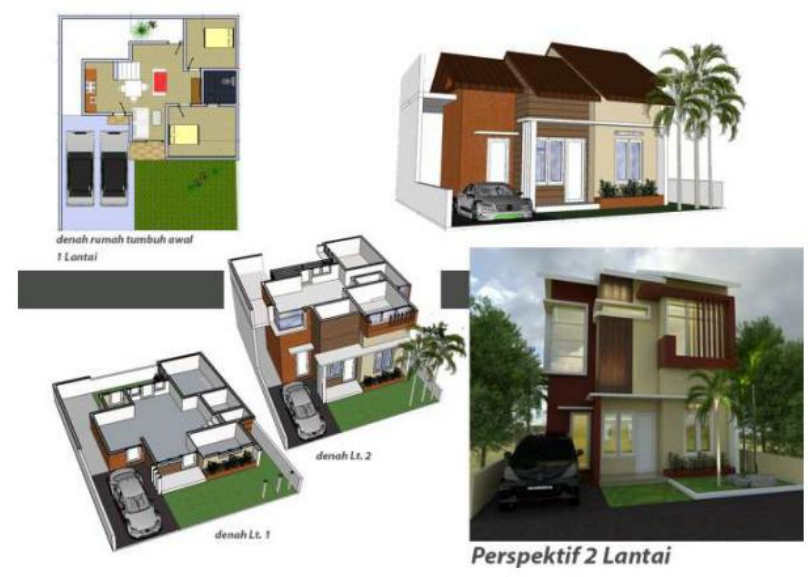

Gambar 1. Pengembangan Rumah Inti Tumbuh secara Horizontal Sumber : Konsep Pengolahan Desain Rumah Tumbuh. (Agusniasnsyah, N. Dkk, 2016)



Gambar 2. Pengembangan Rumah Inti Tumbuh secara Vertikal Sumber : Konsep Pengolahan Desain Rumah Tumbuh (Agusniasnsyah, N. Dkk, 2016) 


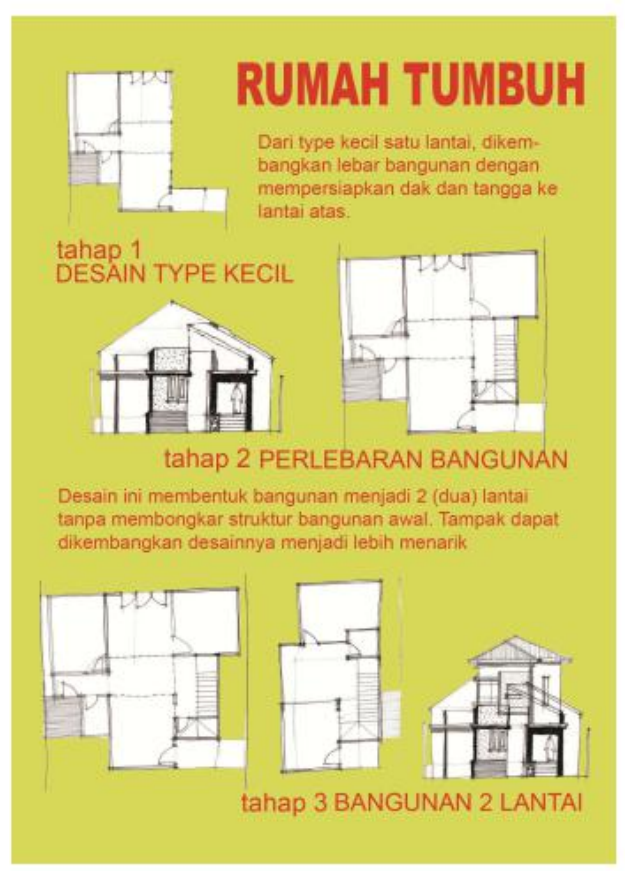

Gambar 3. Pengembangan Rumah Inti Tumbuh Terpadu

Perubahan ataupun penambahan ruang pada rumah inti tumbuh tersebut hanya dapat diterapkan jika memenuhi beberapa persyaratan, seperti yang di sampaikan oleh Abrams (1964: 177) dalam Mark Napier (2002) :

a. Rumah awal harus mampu menampung kegiatan keluarga inti

b. Harus bisa dirancang untuk diperluas oleh rumah tangga sendiri (dengan pelatihan yang tersedia jika diminta) atau lebih mungkin oleh kontraktor kecil

c. harus dimiliki oleh rumah tangga penduduk dengan pinjaman yang tersedia dalam bentuk angsuran untuk membiayai baik inti asli maupun perluasannya,

d. harus berada di sebidang ukuran yang cukup untuk mengakomodasi perluasan menurut beberapa rencana alternatif, menunjukkan rumahrumah yang dibangun untuk menunjukkan alternatif,

e. harus dibangun dari bahan yang memungkinkan perluasan dan yang dapat dipasok melalui pemasok bahan lokal dan produsen yang juga harus dibantu untuk dikembangkan di daerah tersebut,

f. harus dirancang agar nyaman diberikan kondisi iklim lokal, dan harus memiliki akses ke air dan sanitasi.

\subsection{Potensi dan Kelemahan Pengembangan Rumah Inti Tumbuh}

Permasalahan perumahan di Indonesia merupakan salah satu permasalahan yang harus di tangani secara serius. Sering pertumbuhan penduduk yang meningkat derastis, maka kebutuhan akan perumahan semakin meningkat, sedangkan yang terjadi di lapangan, fokus dari perkembangan perkembangan hanya tertuju pada perumahan elit yang dirasa lebih menguntungkan. Keberadaan program rumah inti tumbuh dapat menjadi alternatif untuk mengatasi permasalahan tersebut.

Rumah inti tumbuh memiliki keunggulan dalam desain yang sederhana, yaitu kemudahan konstruksi, dan keterjangkauan. Rumah inti tumbuh dapat dibangun dan 
diperluas tanpa ahli ahli khusus dan dalam waktu singkat. Dengan keunggulan aspek ekonomi, produksi rumah inti tumbuh lebih fleksibel dan lebih ekonomis dibandingkan dengan proyek perumahan yang lebih canggih seperti flat atau apartemen. (E.E. Pandelaki, 2010). Selain itu keunggulan lainnya, pengembangan proyek rumah inti tumbuh, serta jenis lain dari proyek pembangunan perumahan, adalah alat untuk menghasilkan kegiatan ekonomi yaitu lapangan kerja secara langsung dan tidak langsung, melalui padat karya yang membutuhkan banyak jenis industri dan layanan yang dapat disediakan secara lokal.

Di sisi lain pengembangan rumah inti tumbuh juga dapat menyebabkan permasalahan, salah satunya adalah membentuk permukiman kumuh. Seperti yang disampaikan Abram (1966), ketika pengembangan rumah inti tumbuh tidak direncanakan dengan baik sejak awal, proyek pembangunan rumah inti tumbuh dapat bertransformasi menjadi sebuah permukiman yang kumuh. Oleh karenanya dalam pembangunannya harus merencanakan tata letak dan penempatan, serta penyediaan fasilitas publik dan pengembangan lingkungan hijau. Selain itu, permasalahan dalam pengembangan rumah inti tumbuh terdapat pada pendanaan. Menurut E. E. Pandelaki (2010), pembangunan rumah inti tunbuh juga akan terus mengalami kenaikan harga, hal tersebut meliputi kenaikan harga tanah dan material. Oleh karenanya pemerintah terus mengambil peran lebih dalam pengembangan rumah inti tumbuh, agar tidak melenceng dari tujuan awal yaitu menyediakan rumah atau hunian yang layak bagi masyarakat dengan penghasilan menengah ke bawah.

\section{KESIMPULAN}

Rumah merupakan tempat yang sangat bernilai vital bagi perkembangan manusia, rumah merupakan tempat berlindung dan merupakan kebutuhan dasar dari manusia. Oleh karenanya rumah harus memiliki kelayakan untuk menopang segala aktivitas kehidupan sehari-hari secara normal. Namun kelayakan rumah dan perumahan masih menjadi suatu permasalahan di Indonesia, hal ini terjadi akibat pembangunan rumah dan perumahan yang tidak terlalu mempertimbangkan fungsionalitas melainkan lebih berorientasi pada profit. Konsep pengembangan rumah inti tumbuh dapat menjadi alternatif untuk meningkatkan kelayakan rumah dan perumahan di Indonesia dengan beberapa potensi, seperti desain yang sederhana, kemudahan konstruksi, dan keterjangkauan.

Rumah inti tumbuh dapat dibangun dan diperluas tanpa ahli ahli khusus dan dalam waktu singkat. Dengan keunggulan aspek ekonomi, produksi rumah inti tumbuh lebih fleksibel dan lebih ekonomis dibandingkan dengan proyek perumahan yang lebih canggih seperti flat atau apartemen. Disisi lain jika dalam pengembangan rumah inti tumbuh tidak direncanakan dengan baik maka akan berdampak pada berkembangnya kawasan kumuh. Oleh karenanya pengembangan rumah inti tumbuh harus direncanakan dengan baik dan berkesinambungan agar tidak menimbulkan permasalahan perumahan yang lain 


\section{DAFTAR PUSTAKA}

Abram, C. (1966). Housing in the Modern World, Man's Strunggle for Shelter in an Urbanizing World. London: Faber \& Faber Limited.

Agusniansyah, N. (2013). Rumah Tumbuh : Desain Matang Pegang Peran. Jakara: Majalah Nova Edisi 7-13 Oktober.

Agusniansyah, N., \& Widiastuti, K. (2016). Konsep Pengolahan Desain Rumah Tumbuh. Jakarta: Modul Volume 16 Nomer 1 Tahun 2016.

Axellno, G., \& dkk. (2011). Menghitung Biaya Membangun Rumah Tumbuh Tipe 21, 30, 36, 45. Jakarta: PT. Kawan Pustaka.

Budiharjo, E., \& Sudantihardjohubojo. (1993). Kota berwawasan lingkungan. Bandung: PT Alumni.

Dewi, N., \& Swanendri, N. (2007). Perancangan Rumah Tumbuh Tipe KPR BTN di Kota Denpasar. PESAT. Denpasar: Universitas Gunadarma.

E, E. P., \& Shiozaki, Y. (2010). The Core House Concept and Its Implementation in Indonesia : Past, Present, Future. International Jurnal for Housing Science, 233-248.

Habraken, N. I. (1976). Variations : The Systematic Design of Support. Massachusetts: MIT Cambrige.

Haiyono, P. (2007). Sosiologi kota untuk arsitektur. Jakarta: Bumi Aksara.

Napir, M. (2002). The Origin and Spread of Core Housing. Newcastle: University of Newcastle.

Poespowardojo, S. (2006). Beberapa pokok pemikiran fundamental dalam rangka perencanaan perumahan flat dan maisonette, Sejumlah maslaah permukiman kota. Bandung: PT Alumni.

Soebroto, E. P. (2006). Aspek-aspek sosial psikologis pada permukiman masyarakat berpenghasilan rendah di kota-kota besar, Sejumlah permukiman kota. Bandung: PT Alumni.

Susetyo, G. B. (2002). Kajian perubahan pasca huni pembangunan perumahan oleh masyarakat berpenghasilan rendah di kelurahan sungkrah kota surakarta. Semarang: Pascasarjana Undip.

Swanderi, I. M., \& Dewi, N. K. (2010). Rancangan Rumah Tumbuh Tipe 36 dan 45; Laporan Akhir Penelitian Hibah Bersaing Lanjutan Tahun Kedua. Bali: Universitas Udayana.

UNESCAP. (2008). Perumahan bagi kaum miskin di kota-kota asia. Bangkok: United Nation Economic and Social Comission for Asia and The Pacific.

Yarrow, T. (2011). Kinship and The Core House : Contest Ideas of family and place in a Ghanaian resettle twonship. Cambridge University Press, 88-105. 